\title{
Effectiveness of Microfinance Policy in Nigeria, 2010-2017
}

\author{
Melvin Urhuromu Eko-Raphaels ( M.Sc, MEPE) \\ Osadume Chinye Richard (Ph.D, FCA, FCIB) \\ Nigeria Maritime University, Okerenko, Nigeria
}

\begin{abstract}
This study evaluates the effectiveness of microfinance policy in Nigeria from 2010 to 2017. The Study used AMJU Microfinance Bank as its sample and the objectives of the study are to examine appropriate client targeting mechanisms that enhance good microfinance practice aimed at poverty reduction and how client impact evaluation improves operational efficiency and effectiveness. Propensity Score Matching (PSM) technique of micro econometric framework was used to establish the counterfactual for participants. The fundamental evaluation problem of selection bias was treated in the study and primary data obtained through interviews were analysed. The findings show that microfinance client exist rate was on the increase for established clients being significant; and client loan size dissatisfaction for older clients was on the rise and customers that have benefited from microcredits were better-off than non-beneficiaries. The study concludes that Microfinance is effective in poverty reduction and recommends amongst others that the delivery methodology should be tailored after their operational strategy and target clients; and also, appropriate feedback mechanism be built into their product and services delivery to encourage impact evaluation of participants' responses, thereby, providing relevant inputs for the formulation of effective National Microfinance Policy in Nigeria.
\end{abstract}

Keywords: Microfinance, National Microfinance Policy, Financial Services, Financial Development

Classification: Finance, Micro-credit

DOI: $10.7176 / \mathrm{JESD} / 11-2-03$

Publication date: January $31^{\text {st }} 2020$

\subsection{Introduction}

\subsection{Background to the Study}

There has been a growing interest towards recognizing the need to extend financial services freedom to the poor to enable them pursue legitimate economic diversification geared towards survival as well as improving their economic goals. Several schemes were advanced by government to provide the much needed financial succor to this target group, but were characterized by problems such as shallow rooted policy, poor implementation, high default rates, interest rate barriers, corruption and bias allocation (Johnson \& Royaly, 1997; and Morduch, 1999).

The attention paid to this subsector by funding institutions and donor agencies as well as research work by various scholars are yet to yield the expected result on the economy as Nigeria is still ranked among the nations with high poverty index. This study is aimed at investigating the effectiveness of the National Microfinance Policy adopted by the Nigeria government and assessing the extent to which the policy has positively affected poverty level in the country. Unlike the past microfinance impact studies on Nigeria (Anyanwu, 2004; Udy, 1993) that focused on service availability and poverty reduction depth, this study used econometric analysis in assessing the effectiveness of Microfinance policies on Nigeria economy using AMJU UNIQUE (MFB) LTD as sample study.

\subsection{Objectives of the Study}

The primary objective of this study is to evaluate the effectiveness of microfinance policy in Nigeria, studying one of the vibrant performing microfinance institution, AMJU Unique (MFB) Ltd.

The specific objectives are to:

(i) To determine the appropriate client targeting to promote good microfinance practice;

(ii) To ascertain whether impact evaluation of microfinance services helps in improving operational efficiency of microfinance institutions.

\subsection{Hypotheses of the Study}

For the purpose of this study the following hypotheses were tested.

$\mathrm{H}_{\mathrm{o} 1}$ : Client targeting strategy cannot promote good microfinance practice in Nigeria.

$\mathrm{H}_{\mathrm{o} 2}$ : Impact evaluation is not an effective tool for formulation and implementation of national microfinance policy.

\subsection{REVIEW OF RELATED LITERATURE}

\subsection{Conceptual Issues}

Microfinance is a programme that extends small loans (credit) to the poor for self-employment projects that have the capacity to generate income, allowing for sustain ace of the entire family (micro-credit Summit, 1997). 
However, micro-credit is a subset of microfinance. Microfinance is the extension of long term financial services to willing low income bracket in the society.

Microfinance offer financial services in the forms of credits micro-insurance, savings, money transfer, micro portfolio advice and other social services that can enhance the welfare of the poor and its family. It's services can target the rural, semi-rural and/or urban poor to enable income generation and improve standard of living (Townsend and Kaboski, 2005). It is a system of decentralized credit delivery marked by the substitution of individual banking by social intermediation, whose financial intermediaries are people's organizations (Nair, 2001).

Microfinance is seen to be characterized by doorstep service delivery. Transaction in small amounts, collateral substitution and focus on poor especially women (Karlan \& Goldbery, 2006) top reduce poverty and improve selfworth. This is not a one-off or charity lending and not targeted at the upper class of the society.

\subsection{Microfinance Subsector and Financial Development}

Cameron et al (1967) opined that despite the direction of the relationship (growth-inducing or growth-induce), imperati9ve is the quality and efficiency of the services offered by the sector, which include: providing incentives to investors, at low cost 10 encourage huge investments, channeling small funds from savings to encourage entrepreneurial drive, promoting technological progress as it enhances access to banking and creating possibilities for a more efficient allocation of the often unproductive stock of initial wealth in the early stages of industrialization. The need to attain higher levels of growth through financial development which can reduce poverty was supported (Beck et al, 2004). Hence, a sound financial environment predicate a link between financial development and poverty reduction.

Pertinent upon the financial sector development, strategies should include bringing on board the informal sector, a vehicle for uplifting the poor. The informal sector predates the formal sector, hence Johnson (2005) opines the financial sector is intrinsically dualistic. As observed by Wai (1992), there is need by researchers to investigate the informal financial arrangements. Aryeetey and Udy (1997) affirm that the informal financial arrangements are those parts of the overall financial system that fall outside the regulated sector. To this, the arrival of the informal sector is a reprisal to financial repression and regulation (Fry, 1995; Patrick, 1996). Though, inestimable the size of the informal sector, available statistics reveal they form the bulk of the credit needs of the poor (Aryeetey, 1995 and Nissanke, 1991). Thus, the contributions of the informal sector to financial development and poverty reduction cannot be ignored. A major component of the informal sector is the microfinance industry (MFI) that has been evolving over time.

The achievement of the Millennium Development Goal (MOG) is the demarginalization of microfinance programmes (Barr, 2004). To achieve these goals various nations designed approaches and implementation of the economic development programmes. These approaches includes the development of the financial sector involving several return programmes with their attendant implications for poverty reduction through financial markets deepening and institutional capacity building.

\subsection{Microfinance Policy Development Strategies}

Development via the modernization model, especially the direct-credit programmes were frustrated by weak institutions, flourishing corruption, bureaucratic restricts, bloated overhead, transaction costs, poor client targeting and limited products (Morduch, 1999; Adams et al, 1984). Loans were viewed as grants and the institutional framework was viewed with suspicion resulting in loans default. Sometimes halving the entire capital (Hulme and Mosely, 1996 and George, 1990).

The 1970s experienced a new approach to development effort in which there was a mindset viewing economic growth as the main development goal that takes into cognizance, poverty reduction and rural development. Subsequently, in the 1980s, heralded the structural adjustment programme (SAP) in developing economies, coupled with the debt stocks and the acceptance of neo-liberalism by the advanced economies, made way for free market reforms in government intervention in many sectors (Osthoff, 2005; Okojie et al, 2000; Iyoha, 1998; Obadan, 1997; Aryeetey, 1995 and Oyejide, 1993). Thus the government subsidized credit schemes were absorbed by this new development paradigm through the emergence of a more market-based approach. Consequently, the emergence of microfinance however, unusual financial practice, provided financial window to low income brackets. Succinctly put, the failure of past development strategies provoked the emergence and rapid expansion of microfinance (Osthoff, 2005; Moutgomery \& Weiss, 2005; Kabeer, 2005; Barr, 2004; Otero, 1999 and Morduch, 1999).

\subsection{Poverty Alleviation Programme}

Two ways by which the provision of financial services in general and microfinance in particular can have impact on poverty was included in the 2010/2011 world development report, known as the income-generating effect which enhances the poor economies through investment in assets that are affordable. This helps to upgrade the family 
from stable below poverty line to stable above poverty line (Osthoff, 2005) and the vulnerability effect in which families are able to reduce the effects of income fluctuations thereby enhancing consumption smoothening and other coping strategies.

The participation dimension of poverty comprises many forms of deprivation such as humiliation and isolation, powerlessness and social inferiority (Hulme \& Mosley, 1996). In this dimension of poverty, microfinance takes a broader perspective of poverty reduction to include non-material possessions. A major is the extent of empowerment of women. Empowerment strategy breaks the vicious circle of poverty.

\subsection{Microfinance Service Provision}

Microfinance institutions are expected to take into account varying needs of the poor in the design of their products. That is, designing and implementing microfinance services, there is need to consider that credit has varying implications for different segment of the poor and as such could create additional risk for them if not properly directed (Hulme \& Mosely, 1996). Microfinance encompasses both financial and social intermediation including group formation, and training in financial literacy and management practices (Kalpana, 2004). Expedient upon microfinance institutions to diversify their hitherto relatively homogenous products and services to include environmental considerations.

\subsection{Prospective Clients}

The issue of who should constitute a majority of microfinance clients, men or women have been a friction. Some literature have opined female dominated clientele, but recent studies have proven otherwise (Brau \& Woller, 2004; Amm et al, 2003). The argument in favour of women as clients is the assumption of better usage of credits and focus on family. A view of the sustainable Development Goal (SDG) is that women are critical to achieving these goals, hence the motivation to target them. The access to financial services empower women both financially and socially, hence their large number as clients to microfinance (Tassel, 2004) and World Bank (2007) confirm that most microfinance programmes are targeted towards. Women a contrary view was expressed by (Murduch, 1996) suggesting microfinance did not perform better with women as target. However, gender is not a determinant of poverty or poverty being gender sensitive.

\subsection{The Business of Microfinance Banking in Nigeria}

Nigeria is endowed with a huge population of abo9ut 200 million people as at 2018 , of which $60 \%$ is predominantly rural (NBC, 2016) with a physical spread of $923,768 \mathrm{~km}^{2}$. A West African country and strong player in regional economics and politics, bounded in the North by the Nigeria Republic, west by Benin Republic, east by the Chad and Cameroun and Gulf of Guinea in the South. It comprises of 36 Administrative states and a federal capital reserve, Abuja. These broken down into 774 local government areas (LGAs). She got her political independence in October of 1960, an hitherto colony of Britain. For over two decades, it was administered by the military. In May of 1999 a new democratic setting emerged and still running till date. Despite its seemly progress, it still parade indices of poverty characterized by unchecked population growth, slow development, unstable macroeconomic environment buffeted by internal and external crisis and a micro economy, heavily reliant on crude petroleum. The discovery, which have relegated other sectors. The cry for economic diversification had been on, but only serious when oil and gas price shocks are experienced and relapses as soon as the price is stable. The current dispensation is giving an unserious try to this effort but laden with huge debt. As at the time of this study, it owed $\$ 6.7$ trillion external debt and $\$ 22.4$ trillion internal debt with $15 \%$ attracted bytes 36 states of the country.

Specifically, in terms of macroeconomic indicators, Nigeria witnessed a consistent decline in growth rate, Gross Domestic Product (GDP) and rising inflation consecutively between 2014-2017, thereby eroding the saving capability of most households. Nigeria economy is also experiencing an increase in debt to GDP ratio resulting in low foreign investment and inability of the government to meet developmental programmes in the areas of poverty alleviation, infrastructural development and jobs creation. Also, credit extension to the private sector is low, limiting their capabilities of investment activities vis-à-vis poverty reduction.

\subsection{Theoretical Issues in Microfinance}

There is increasing need among development agencies, donors, government and private concerns to undertake a robust evaluation of any intervention programme. The fundamental question to address about a programme is if objectives have been met within cost. In other words, impact evaluation can provide information on whether a programme measurably benefits participants in comparison with those who did not participate. Although, many stakeholders are eager to undertake formal evaluation of their programmes due to cost implications and the limitation of the outcomes of evaluation (Ogiogio, 2006). A main constraint encountered in most evaluation programmes is getting key players to agree to conducting the evaluation as fear of vested interest may be hindered or due to other ethical objectives. Again, many organisation regard negative findings as hindrance to foster their agenda (Ravillion, 2005; Hulme, 2000 and 1997; and Baker, 1999). Despite these apprehension, the benefits of 
conducting impact evaluation are huge (Karlan \& Goldberg, 2006).

To have a proper understand of the right methodology to employ in an impact evaluation, there is the need to have a grasp of the basic concept of impact evaluation. The World Bank (2002) defined impact evaluation on a "systematic identification of the effects on individuals, households, institutions and the environment caused by a given development activity such as a programme or project". Evaluation can be analytical assessment of a programme (OECD, 1999). Thus, an evaluation can take the form of beneficiary assessment, indicator monitoring, public expenditure tracking survey, rapid appraisals, concurrent assessment policy-level assessment and tracer studies (Bloomquist, 2003). It is aimed at assessing programmes performance against explicit counterfactual, such as the situation in the absence of the programme (Ravallion, 2005). Impact evaluation therefore, can be both exante and ex-post.

\subsection{Empirical Literature on Microfinance}

Pitt et al (2003) also evaluated the Bangladesh (BRAC, BRDB, Grameen bank) using the maximum likelihood estimation controlling for endogeity of individual participation and of placement of microfinance programmes. Impact variables being health of men and women (arm measure, body mass under (BMI) and height-for-age). Result shows significantly positive effects of female credit on height-for-age and arm circumference of both men and women. Borrowing by men has either negative or non-significant impact on health of children.

Amin et al (2003) examined Bangladesh (ASD, Grameen Bank, BRAC) using non parametric test of stochastic dominance of average monthly consumption or members and nonmembers and maximum likelihood test of micro credit membership on vulnerability, consumption and household characteristics. Findings indicate members are poorer than non-members. Programmes are more successful at reaching the vulnerable.

Kaboski and Townsend (2002) tested Thailand (production credit groups, rice banks, women groups, buffalo banks) using two stage LS and MLE test of microfinance impact on asset growth, probability of reduction in consumption in bad years, probability of becoming money lender, probability of starting business and probability of changing job. Separate estimation according to types of MFI. Result were that production credit groups and women groups combined with training and savings have positive impact on asset growth, although rice banks and buffalo banks have negative impacts. Emergency services training and savings help to smooth responses to income shock. Women groups help to reduce reliance on money lenders.

\subsection{Data and Methodology \\ 3.1 Sources of Data and Description}

This study makes use of cross-section data of primary nature. A sample of six hundred and forty (640) clients of AMJU (MFB) Ltd, an MFI licensed by the Central Bank of Nigeria (CBN) under Banks and other financial Institution (BOFIA)I Act No.25 of 1999. It started operation in May, 2000.

This study utilized cross-section data. A sample of six hundred and forty (640) clients of AMJU, an MFI in Nigeria was used.

The poverty scores were calibrated as: Least poor $=0-27$ code $(12)$, Less poor $=(28-45)$ code $(2)$, average poor $=(46-63)$, code $(3)$, poor $=(64-82)$ code $(4)$ and poorest $=(84-100)$ code $(5)$. High scores are assigned to low level of the poverty indicators. A client is registered as a member to participate in AMJU programmes if his/her poverty score is at least 46 (i.e. average poor to poorest). Thus, programme placement is determined by a "proxymeans test" (assignment of a score to all potential participants as a function of observable characteristics) as often used for targeting anti-poverty programmes in developing countries (Ravallion, 2005).

\subsection{Sample Selection}

The sample was drawn from twenty (20) unions spread across ten (10) branches in five locations. The observable characteristics of interest include: age, sex, previous business experience (in years), loan stage, loan type and location. Data were also collected on marital status, education level, primary business and poverty scores at registration for membership and on completion of loan cycle. In line with Heckman, Ichimura and Todd (1997), these variables are those that influence simultaneously the participation decision as well as the outcome variable. Furthermore, the variables are either fixed over time or are measured before participation. Also as noted by Heckman, Lalonde, and Smith (1999), the data for both the treatment and non-treatment groups are from the same population, a basic requirement for matching. All variables were categorical data, hence reflecting only the direction of change and not the exact magnitude.

In addition to the pipeline comparator, this study also employed propensity score matching to correct for selection bias. Analysis of the characteristics of all clients was used to create the control group. To validate these observables, we carried out a qualitative fieldwork of a sample of clients of AMJU. A propensity function was generated linking client characteristics to the likelihood that a client will access loan from the programme on members. The results of a recent study by Frölich (2006) on Gender Wage Gap of College Graduates in the UK showed that the propensity score matching is justified under the same assumption than matching on covariates and 
that choice-based sampling can be ignored. In other words, PSM can be applied without conditional independence assumption and on non-independently and identically distributed (iid) data. Hence, PSM allows estimation of mean impacts without arbitrary assumptions about functional forms and error distributions. This facilitates testing for the presence of potentially complex interaction effects.

\subsection{Model Specification}

For an anti-poverty programme, the objective is usually defined in terms of household income or expenditure (on consumption) normalized by a household specific poverty score.

Given that the impact on poverty is known, then set $\mathrm{Y}=1$ as the outcome with treatment and $\mathrm{Y}=0$ as the outcome without treatment. Since an individual cannot be in both states, then it is not possible to observe $\mathrm{Y}=0$ and $\mathrm{Y}=1$ for the same individual thereby leading to the problem of missing data (Essama-Nssah, 2006; Ravallion, 2005 and Wooldridge, 2002). To guard against the possibility of the case where the treatment of one unit affects another's outcome as may be in general equilibrium effect (Heckman et al., 1998), the sample from the population is assumed to be independently and identically distributed (iid). In many cases the outcomes $\mathrm{Y}=0$ and $\mathrm{Y}=1$ are binary.

Let the variable $\mathrm{T}$ be a binary treatment indicator, such that $\mathrm{T}=1 \mathrm{implies}$ treatment and $\mathrm{T}=0$ denotes without treatment. Presuming that the data include an observation $Y_{1}$ for each unit $I$ in a sample of size $n$. The value $Y_{i}$ under treatment is $\mathrm{Y}_{\mathrm{i}}^{\mathrm{T}}$ and $\mathrm{Y}_{\mathrm{i}}^{\mathrm{C}}$ under the counterfactual of not receiving treatment. The benefit (gain) to unit ${ }_{\mathrm{i}}$ who received treatment is given as:

$\mathrm{G}_{\mathrm{i}}=\mathrm{Y}_{\mathrm{i}}^{\mathrm{T}}-\mathrm{Y}_{\mathrm{i}}^{\mathrm{C}} \mid \mathrm{T}=1$

As noted above, due to the problem of missing data, we assume that we can only observe $\mathrm{T}_{\mathrm{i}}, \mathrm{Y}_{\mathrm{i}}^{\mathrm{T}}$ for $\mathrm{T}_{\mathrm{i}}=1 ; \mathrm{Y}_{\mathrm{i}}^{\mathrm{C}}=$ 0 and thus, the fundamental problem of evaluating this individual treatment effect arises because the observed outcome for each individual is given by:

$\mathrm{Y}_{\mathrm{i}}=\mathrm{T}_{\mathrm{i}} \mathrm{Y}_{\mathrm{i}}^{\mathrm{T}}+\left(1-\mathrm{T}_{\mathrm{i}}\right) \mathrm{Y}_{\mathrm{i}}^{\mathrm{C}}$

The average gain, which is the mean of all the Gs gives the sample mean gain for all the treated. This is called the average treatment effect on the treated (ATET) given by:

$\mathrm{ATET}=\mathrm{E}(\mathrm{G} \mid \mathrm{T}=1)=\mathrm{E}\left(\mathrm{Y}^{\mathrm{T}} \mid \mathrm{T}=1\right)-\mathrm{E}\left(\mathrm{Y}^{\mathrm{C}} \mid \mathrm{T}=1\right) \ldots$

Equation (3.19) is the mean impact on poverty among those who actually received the programmes. In other words, ATET is the difference between expected outcome values with and without treatment for those who actually participated in treatment. Similarly, the average treatment effect on the untreated (ATEUT) is given as:

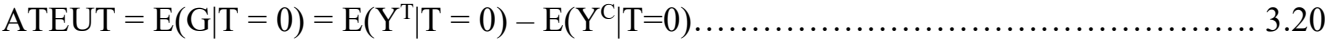

The overall mean impact of the programme is the sum of equations (3.19) and (3.20) called the average treatment effect given by:

Ate $=\mathrm{E}(\mathrm{G})=\mathrm{ATET}+\mathrm{ATEUT}$

Consider $\mathrm{X}$ as a vector of covariates (observable characteristics), then interest may be on the following conditional mean impacts.

$\operatorname{ATET}(\mathrm{X})=\mathrm{E}(\mathrm{G} \mid \mathrm{X}, \mathrm{T}=1)$

$\operatorname{ATEUT}(\mathrm{X})=\mathrm{E}(\mathrm{G} \mid \mathrm{X}, \mathrm{T}=0)$

$\operatorname{ATE}(\mathrm{X})=\mathrm{E}(\mathrm{G} \mid \mathrm{X})$

Frolic (2006), Ravallion (2005) and Wooldridge (2002) agree that the most common method of introducing $X$ assumes that the Y's are linear in the their parameters and the error terms $\left(\mu^{\mathrm{T}}\right.$ and $\left.\mu^{\mathrm{C}}\right)$. hence we have regression equations given as:

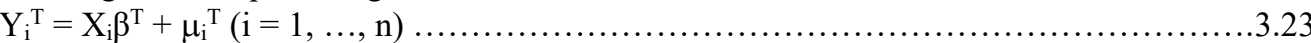

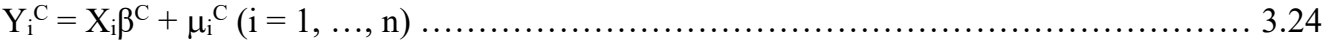

Basically in equations (3.23) and (3.24), $\mathrm{X}$ is assumed to be exogenous, hence,

$\mathrm{E}\left(\mu^{\mathrm{T}} \mid \mathrm{X}\right)=\mathrm{E}\left(\mu^{\mathrm{C}} \mid \mathrm{X}\right)=0$

The mean impacts are derived as:

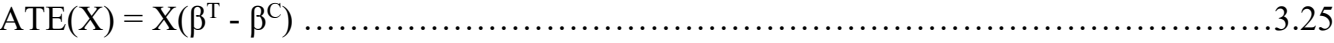

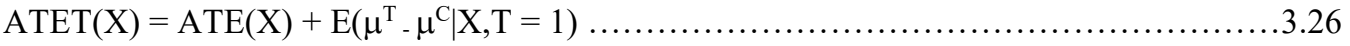

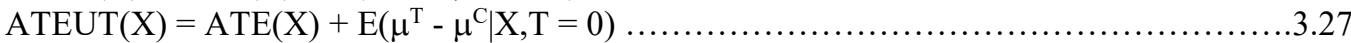

It should be noted that $\mathrm{G}_{\mathrm{i}}$ cannot be observed directly for any $\mathrm{i}$ since data on $\mathrm{Y}_{\mathrm{i}}^{\mathrm{T}}$ for $\mathrm{T}_{\mathrm{i}}=0$ and $\mathrm{Y}_{\mathrm{i}}^{\mathrm{C}}$ for $\mathrm{T}_{\mathrm{i}}=1$ are missing. Again, without further assumption, it may not be possible to identify the impacts since $e\left(\mathrm{Y}^{\mathrm{C}} \mid \mathrm{T}=1\right) \mathrm{j}$ and $\mathrm{E}\left(\mathrm{Y}^{\mathrm{T}}=0\right)$ are not directly estimable from the data. However, we can form a control group or develop an econometric modeling strategy that provides a consistent estimate. Also, equations (3.23) and (3.24) no longer constitute estimable models in view of the problem of missing data. To obtain a point estimate on mean impact, the starting point is to adopt the approach of the simple-difference (D) in the conditional mean outcome between the treated and the non-treated. This is based on the assumption of ignorability of treatment introduced by Rosenbaum and Rubin (1983) stated as follows:

Assumption 2.1: Conditional on $X$, then $T$ and $\left(Y^{T}, Y^{C}\right)$ are independent. 
Hence, the single - difference is given as:

$\mathrm{D}(\mathrm{X})=\mathrm{E}\left(\mathrm{Y}_{\mathrm{i}}^{\mathrm{T}} \mid \mathrm{X}_{\mathrm{i}}, \mathrm{T}_{\mathrm{i}}=1\right)-\mathrm{E}\left(\mathrm{Y}_{\mathrm{i}}^{\mathrm{C}} \mid \mathrm{X}_{\mathrm{i}}, \mathrm{T}_{\mathrm{i}}=0\right)$

Equation (3.28) can be estimated by the difference in the corresponding sample means or equivalently by the Ordinary Least Squares (OLS) regression coefficient of Y on T.

For the parametric model with controls, equation (3.23) can be estimated on the sample of treated while equation (3.24) on the rest of the sample, therefore resulting in the following estimable model.

$\mathrm{Y}_{\mathrm{i}}^{\mathrm{T}}=\mathrm{X}_{\mathrm{i}} \beta^{\mathrm{T}}+\mu^{\mathrm{T}} \mathrm{ifT}_{\mathrm{i}}=1$

$\mathrm{Y}_{\mathrm{i}}^{\mathrm{C}}=\mathrm{X}_{\mathrm{i}} \beta^{\mathrm{C}}+\mu_{\mathrm{i}} \mathrm{C}_{\mathrm{ifT}} \mathrm{T}_{\mathrm{i}}=0$

Ravallion (2005) explains that the common practice is to estimate a simple ("switching") regression for the observed outcome measure on the pooled sample, leading to a "random coefficient" specification. Substituting equations (3.29) and (3.30) into the identity $\mathrm{Y}_{\mathrm{i}}=\mathrm{T}_{\mathrm{i}} \mathrm{Y}_{\mathrm{i}}^{\mathrm{T}}+\left(1-\mathrm{T}_{\mathrm{i}}\right) \mathrm{Y}_{\mathrm{i}}^{\mathrm{C}}$ at equation (3.18), then we have:

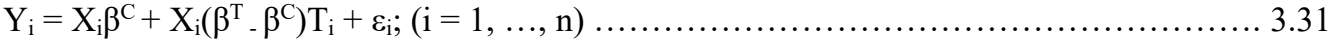

Where $\varepsilon_{\mathrm{i}}=\mathrm{T}_{\mathrm{i}}\left(\mu_{\mathrm{i}}^{\mathrm{T}}-\mu_{\mathrm{i}}^{\mathrm{C}}\right)+\mu_{\mathrm{i}}^{\mathrm{C}}$

Adopting the common-impact-model for which $\mathrm{G}_{\mathrm{i}}=\mathrm{G}$, then equation (3.31) becomes a regression of $\mathrm{Y}$ on $\mathrm{T}$ and $\mathrm{X}$ given by:

$Y_{i}=\left(\beta_{o}{ }^{T}-\beta_{o}{ }^{C}\right) T_{i}+X_{i} \beta^{C}+\varepsilon_{i}$

Where $\beta_{\mathrm{o}}{ }^{\mathrm{T}}$ and $\beta_{\mathrm{o}}{ }^{\mathrm{C}}$ are the intercepts in equations (3.29) and (3.30) and $\varepsilon_{\mathrm{i}}=\mu_{\mathrm{i}} \mathrm{C}^{\mathrm{C}}$.

To obtain unbiased impact estimates, we first consider the difference in mean outcome between the treated and non-treated at equation (3.28). This can be re-written as:

$\mathrm{D}(\mathrm{X})=\mathrm{ATE}(\mathrm{X})+\mathrm{BLAS}^{\mathrm{ATET}}(\mathrm{X})$

Hence, the bias is:

$\operatorname{BLAS}^{\mathrm{ATET}}(\mathrm{X})=\mathrm{E}\left(\mathrm{Y}^{\mathrm{C}} \mid \mathrm{X}, \mathrm{T}=1\right)-\mathrm{E}\left(\mathrm{Y}^{\mathrm{C}} \mid \mathrm{X}, \mathrm{T}=0\right)$

Also, for the un-treated, the bias is obtained as:

$\operatorname{BIAS}^{\text {ATEUT }}(\mathrm{X})=\mathrm{E}\left(\mathrm{Y}^{\mathrm{T}} \mid \mathrm{X}, \mathrm{T}=1\right)-\mathrm{E}\left(\mathrm{Y}^{\mathrm{T}} \mid \mathrm{X}, \mathrm{T}=0\right)$

Then the bias for the average treatment effect is:

$\operatorname{BIAS}^{\mathrm{ATE}}(\mathrm{X})=\operatorname{BIAS}^{\mathrm{ATET}}(\mathrm{X}), \operatorname{Pr}(\mathrm{T}=1)-\operatorname{BIAS}^{\mathrm{ATEUT}}(\mathrm{X}) \cdot \operatorname{Pr}(\mathrm{T}=0)$

If we assume that BIAS ${ }^{\mathrm{ATET}}=0$, then OLS applied to equation (3.32) will produce consistent estimation.

\subsubsection{Assessing the Matching Quality}

To ensure that the matching procedure is able to balance the distribution of the relevant variables in both the control and treatment group, the quality of matching can be assessed using the Heckman-Hotz (1989) indirect test, standardized Bias, t-test, Joint significance and Pseudo- $\mathrm{R}^{2}$ and Stratification test.

The Standardized Bias is used the distance in marginal distribution of the X-variables. For each covariate $\mathrm{X}$, this is defined as the difference of sample means in the treated and matched control sub-samples as a percentage of the square root of the average of sample variances in both groups. The standardized bias for before and after matching are given as follows:

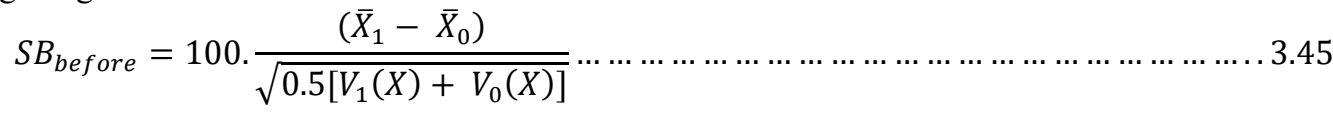

And

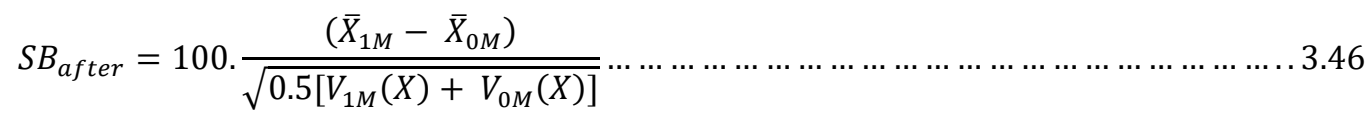

Where $\bar{X}_{1}\left(V_{1}\right)$ is the mean (variance) in the treatment group before matching and $\bar{X}_{0}\left(V_{0}\right)$ the analogue for the control group. $\bar{X}_{1 M}\left(V_{1 M}\right)$ and $\bar{X}_{O M}\left(V_{o M}\right)$ are the corresponding values for the matched samples.

The t-test uses a two-sample t-test to check if there are significant differences in covariate mean for the two groups (Rosebaum \& Rubin, 1985). The Pseudo- $\mathrm{R}^{2}$ shows the extent the regressors X explain the probability of participation. The stratification test is used to t4est after dividing the observations into strata, if within each stratum the distribution of $\mathrm{X}$-variables is the same for both groups.

\subsubsection{Estimating the Variance of Treatment Effects}

The variances of the treatment effects (ATE and ATET) are not usually easy to compute because of the inclusion of the variance due to estimation of the propensity score (Caliendo \& Kopeinig, 2005). However, under unconfoundedness assumption, Haln (1998) estimated the asymptotic variances of ATT and ATET as follows:

And

$$
\operatorname{Var}_{A T E}=E\left[\frac{\sigma_{1}^{2}(X)}{P(X)}+\frac{\sigma_{0}^{2}(X)}{1-P(X)}+\left(E\left(Y^{T} \mid X-E\left(Y^{C} \mid X\right)-A T E\right)^{2}\right]\right.
$$

$$
\operatorname{Var}_{A T E T}^{P \text { Sunknown }}=E\left[\frac{P(X) \sigma_{1}^{2}(X)}{P(X)}+\frac{P(X) \sigma_{0}^{2}(X)}{E[P(X)]^{2}(1-P(X))}+\frac{\left.\left(E\left(Y^{T} \mid X\right)-E^{C} \mid X\right)-A T E\right)^{2} P(X)}{E[P(X)]^{2}}\right] \ldots
$$

Where $\sigma_{T}^{2}(X)$ are the conditional outcome variance for the treated $(\mathrm{T}=1)$ and untreated $(\mathrm{T}=0)$ observations. The estimation of the above variances can be carried out by variance approximation by Lechner (2001) through 
nearest-neighbour $(\mathrm{NN})$ matching as follows

$\operatorname{Var}(A T E T)=\frac{1}{N_{1}} \operatorname{vAR}\left(Y^{T} \mid T=1\right)+\frac{\left(\sum_{j \in\{T=0}\left(\omega_{j}\right)^{2}\right.}{\left(N_{1}\right)^{2}} \cdot \operatorname{Var}\left(Y^{C} \mid T=0\right)$

Where $\mathrm{N}_{1}$ is the number of matched treated individuals and $\omega_{j}$ is the number of timers individual $\boldsymbol{j}$ from control group has been used taking into account matching with replacement. The approach assumes homescedasticity of the variances of the outcome variables within treatment and control groups.

To distinguish between population and variances, Abadie and Imbens (2006) estimated the sample-average treatment effect on the treated (SATET) as:

$$
\text { SATET } \quad=\frac{1}{N_{1}} \sum_{i \in\{T=1\}}\left[Y^{T}-Y^{C}\right]
$$

Depriving a matching variance estimator that does not require additional non-parametric estimation, the variance or SATET is given by:

$$
\operatorname{Var}(S A T E T)=\frac{1}{N_{1}} \sum\left[T_{1}-\left(1-T_{1}\right) \cdot \frac{K_{M}(i)}{M}\right]^{2} \cdot \hat{\sigma}_{T}^{2}\left(X_{1}\right)
$$

Where $\mathbf{M}$ is the number of matches and $\mathbf{K}_{\mathbf{M}}(\mathbf{i})$ is the number of times unit $\mathbf{i}$ is used as a match.

\subsection{Counterfactual Construction}

This study adopted the application of quasi-experimental design because of its ability to resolve problems of endogeneity associated with non-random programme placement and self-selection of members of the treatment group. The matching method using pipeline comparison group was adopted where the control group consisted of those clients who were assessed as poor, registered as members of the microfinance programme but were yet to access loans or had accessed loan the first time but were yet to complete their first loan cycle. In this study, the treatment and control group, have similar observable characteristics as portrayed by the poverty score at point of registration in addition to the demographic characteristics, thus, the issue of selection bias has been reduced. This matching ability of the control group was established using equations (3.37) to 3.44).

Galasso and Ravallion (2004) and Chase (2002) affirm that the use of pipeline comparison helps to address the problem of latent heterogeneity. Testing for observable differences between the treatment and non-treatment, Galasso and Ravallion (2004) in their study of Social Protection Programme in Argentina in which the pipeline comparison was adopted, found that the observables including idiosyncratic shocks were well balanced between the two groups. Thus, for this study, the pipeline comparator was employed because there has not been any material change in the criteria for registration as a member of AMJU programmes.

\subsection{Presentation and Analysis of Empirical Results}

\subsection{Characteristics of AMJU Clients}

In terms of gender targeting, about $82.8 \%$ of the union members of AMJU programmes are female members (Table 4.1). This is consistent with AMJU's mission of empowering poor clients who are locked out of institutional credit due to lack of command over land, stocks and other forms of acceptable collaterals.

\begin{tabular}{|c|c|c|c|c|c|c|}
\hline \multirow[b]{2}{*}{ Sex } & \multicolumn{2}{|c|}{ Treatment group } & \multicolumn{2}{|c|}{ Non-Treatment Group } & \multicolumn{2}{|c|}{ All Clients } \\
\hline & $\begin{array}{l}\text { No. } \\
523\end{array}$ & $\%$ & $\begin{array}{l}\text { No. } \\
117\end{array}$ & $\%$ & $\begin{array}{l}\text { No. } \\
640\end{array}$ & $\%$ \\
\hline $\begin{array}{l}\text { Male } \\
\text { Female }\end{array}$ & $\begin{array}{c}90 \\
433\end{array}$ & $\begin{array}{l}17.2 \\
82.8\end{array}$ & $\begin{array}{c}12 \\
105\end{array}$ & $\begin{array}{l}10.3 \\
89.7\end{array}$ & $\begin{array}{l}102 \\
538\end{array}$ & $\begin{array}{l}17.2 \\
82.8\end{array}$ \\
\hline
\end{tabular}

Table 4.1: Gender Distribution of Sampled Clients at Registration

Source(s): Author's Computation.

\begin{tabular}{|c|c|c|c|c|c|c|}
\hline \multirow[b]{2}{*}{ Age (years) } & \multicolumn{2}{|c|}{ Treatment group } & \multicolumn{2}{|c|}{ Non-Treatment Group } & \multicolumn{2}{|c|}{ All Clients } \\
\hline & $\begin{array}{l}\text { No. } \\
523\end{array}$ & $\%$ & $\begin{array}{l}\text { No. } \\
117\end{array}$ & $\%$ & $\begin{array}{l}\text { No. } \\
640\end{array}$ & $\%$ \\
\hline $18-25$ & 18 & 3.4 & 6 & 5.1 & 24 & 3.8 \\
\hline $26-35$ & 174 & 33.3 & 48 & 41.0 & 222 & 34.7 \\
\hline $36-45$ & 198 & 37.9 & 43 & 36.8 & 241 & 37.7 \\
\hline $46-55$ & 103 & 19.7 & 12 & 10.3 & 115 & 18.0 \\
\hline $56-65$ & 23 & 4.4 & 7 & 6.0 & 30 & 4.7 \\
\hline 66 and above & 7 & 1.3 & 1 & 0.9 & 8 & 1.3 \\
\hline
\end{tabular}

Table 4.2: Age Distribution of Sampled Clients at Registration

Source(s): Author's Computation.

About $94.3 \%$ of the sampled clients are between 26 and 55 years of age. This age bracket is the bedrock of the economically active population. It reflects good targeting for a microfinance institution whose mission is to 
assist the active poor to build viable and sustainable micro-enterprises.

Table 4.3: Level of Education of Sampled Clients at Registration

\begin{tabular}{|c|c|c|c|c|c|c|}
\hline \multirow[b]{2}{*}{ Education } & \multicolumn{2}{|c|}{ Treatment group } & \multicolumn{2}{|c|}{ Non-Treatment Group } & \multicolumn{2}{|c|}{ All Clients } \\
\hline & $\begin{array}{l}\text { No. } \\
523\end{array}$ & $\%$ & $\begin{array}{l}\text { No. } \\
117\end{array}$ & $\%$ & $\begin{array}{l}\text { No. } \\
640\end{array}$ & $\%$ \\
\hline No Education & 20 & 3.8 & 5 & 4.3 & 25 & 3.9 \\
\hline Half Primary & 38 & 7.3 & 4 & 3.4 & 42 & 6.6 \\
\hline Full Primary & 165 & 31.5 & 29 & 24.8 & 194 & 30.3 \\
\hline Half Secondary & 90 & 17.2 & 24 & 20.5 & 114 & 17.8 \\
\hline Full Secondary & 196 & 37.5 & 51 & 43.6 & 247 & 38.6 \\
\hline Tertiary & 14 & 2.7 & 4 & 3.4 & 18 & 2.8 \\
\hline
\end{tabular}

Source(s): Author's Computation.

Most AMJU clients (about 89\%) have a minimum of full primary education. This facilitates better communication between AMJU staff and the clients. Also, it helps clients to quickly understand AMJU's philosophy and enhancing their skills in new business development.

Table 4.4: Marital Status of Sampled Clients at Registration

\begin{tabular}{|c|c|c|c|c|c|c|}
\hline \multirow[b]{2}{*}{ Marital Status } & \multicolumn{2}{|c|}{ Treatment Group } & \multicolumn{2}{|c|}{ Non-Treatment Group } & \multicolumn{2}{|c|}{ All Clients } \\
\hline & $\begin{array}{l}\text { No. } \\
523\end{array}$ & $\%$ & $\begin{array}{l}\text { No. } \\
117\end{array}$ & $\%$ & $\begin{array}{l}\text { No. } \\
640\end{array}$ & $\%$ \\
\hline Married & 417 & 79.7 & 91 & 77.8 & 508 & 79.4 \\
\hline Living with a companion & 30 & 5.7 & 11 & 9.4 & 41 & 6.4 \\
\hline Single/never married & 26 & 5.0 & 6 & 5.1 & 32 & 5.0 \\
\hline Single/Divorced & 16 & 3.1 & 5 & 4.3 & 21 & 3.3 \\
\hline Single/Widowed & 34 & 6.5 & 4 & 4.3 & 21 & 3.3 \\
\hline
\end{tabular}

\section{Source(s): Author's Computation.}

The majority, about $90.0 \%$ of the clients sampled have lived with a partner or have been married. This is a good parameter in group formation as only $5.0 \%$ of the clients had not been involved in marital affairs. There is implied sense of responsibilities among clients as the microfinance services are expected to be directed towards the well-being of the families of clients.

Table 4.5: Location of Sampled Clients at Registration

\begin{tabular}{|l|c|c|c|c|c|c|}
\hline \multirow{2}{*}{ Location } & \multicolumn{2}{|c|}{ Treatment group } & \multicolumn{2}{c|}{ Non-Treatment Group } & \multicolumn{2}{c|}{ All Clients } \\
\cline { 2 - 7 } & No. & & No. & $\%$ & No. & \\
& 523 & $\%$ & 117 & 70 & 640 & $\%$ \\
\hline Urban/Semi-Urban & 312 & 59.7 & 70 & 59.8 & 382 & 59.7 \\
Rural & 211 & 40.3 & 47 & 40.2 & 258 & 40.3 \\
\hline
\end{tabular}

Source(s): Author's Computation.

About sixty percent $(60 \%)$ of AMJU clients are in the urban/semi-urban areas because of high population density. This facilitates group formation at low cost. However, most rural poor are excluded from benefiting from such services because of risk-return considerations. As noted by ADB (2000), most private MFIs are reluctant to invest in financial technology and innovative programmes oriented to the rural poor because the belief is that the market among the poor is limited and externalities will not allow the MFIs to profit from their investments.

Table 4.6: Previous Business Experience of Sampled Clients at Registration

\begin{tabular}{|c|c|c|c|c|c|c|}
\hline \multirow[b]{2}{*}{$\begin{array}{c}\text { Years of Previous Business } \\
\text { Experience }\end{array}$} & \multicolumn{2}{|c|}{ Treatment group } & \multicolumn{2}{|c|}{ Non-Treatment Group } & \multicolumn{2}{|c|}{ All Clients } \\
\hline & $\begin{array}{l}\text { No. } \\
523\end{array}$ & $\%$ & $\begin{array}{l}\text { No. } \\
117\end{array}$ & $\%$ & $\begin{array}{l}\text { No. } \\
640\end{array}$ & $\%$ \\
\hline Less than one 1 year & 7 & 1.3 & 4 & 3.4 & 11 & 1.7 \\
\hline $1-3$ years & 121 & 23.1 & 30 & 25.6 & 151 & 23.6 \\
\hline 4-6 years & 130 & 24.9 & 49 & 41.9 & 179 & 28.0 \\
\hline $7-9$ years & 151 & 28.9 & 22 & 18.8 & 173 & 27.0 \\
\hline 10 years and above & 114 & 21.8 & 12 & 10.3 & 126 & 19.7 \\
\hline
\end{tabular}

\section{Source(s): Author's Computation.}

It appears that prior knowledge of a business is a requirement for eligibility to participate in AMJU programmes. This is probably to guard against fungibility of money and thus ensure that clients use the micro loans for intended purpose (improving their businesses) and thus translate to improvement in the general wellbeing of clients. 
Table 4.7: Loan Stage of Sampled Clients at Registration

\begin{tabular}{|c|c|c|c|c|c|c|}
\hline \multirow[b]{2}{*}{ Loan Stage } & \multicolumn{2}{|c|}{ Treatment group } & \multicolumn{2}{|c|}{ Non-Treatment Group } & \multicolumn{2}{|c|}{ All Clients } \\
\hline & $\begin{array}{l}\text { No. } \\
523\end{array}$ & $\%$ & $\begin{array}{l}\text { No. } \\
117\end{array}$ & $\%$ & $\begin{array}{l}\text { No. } \\
640\end{array}$ & $\%$ \\
\hline 0 & 0 & 0.0 & 117 & 100.0 & 117 & 18.3 \\
\hline 1 & 0 & 0.0 & 0 & 0.0 & 0 & 0.0 \\
\hline 2 & 238 & 45.5 & 0 & 0.0 & 238 & 37.2 \\
\hline 3 & 37 & 7.1 & 0 & 0.0 & 37 & 5.8 \\
\hline 4 & 77 & 14.7 & 0 & 0.0 & 77 & 12.0 \\
\hline 5 & 51 & 9.8 & 0 & 0.0 & 51 & 8.0 \\
\hline 6 & 28 & 5.4 & 0 & 0.0 & 28 & 4.4 \\
\hline 7 & 40 & 7.6 & 0 & 0.0 & 40 & 36.3 \\
\hline 8 & 33 & 6.3 & 0 & 0.0 & 33 & 5.2 \\
\hline 9 and above & 19 & 3.6 & 0 & 0.0 & 19 & 3.0 \\
\hline
\end{tabular}

Source(s): Author's Computation.

From table 4.7, it is evident that members of the treatment group are clients in their second loan stage or more while the control group consists of clients yet to receive any loan. This enhances the construction of appropriate counterfactual.

Table 4.8: Poverty Targeting of Clients at Registration

\begin{tabular}{|c|c|c|c|c|c|c|}
\hline \multirow[b]{2}{*}{ Poverty Score } & \multicolumn{2}{|c|}{ Treatment group } & \multicolumn{2}{|c|}{ Non-Treatment Group } & \multicolumn{2}{|c|}{ All Clients } \\
\hline & $\begin{array}{l}\text { No. } \\
523\end{array}$ & $\%$ & $\begin{array}{l}\text { No. } \\
117\end{array}$ & $\%$ & $\begin{array}{l}\text { No. } \\
640\end{array}$ & $\%$ \\
\hline Least Poor (0-27) & 0 & 0.0 & 0 & 0.0 & 0 & 0.0 \\
\hline Less Poor (28-45) & 10 & 1.9 & 2 & 1.7 & 12 & 1.9 \\
\hline Average Poor (46-63) & 311 & 59.5 & 62 & 53.0 & 373 & 58.3 \\
\hline Poor $(64-81)$ & 190 & 36.3 & 50 & 42.7 & 240 & 37.5 \\
\hline Poorest (84-100) & 12 & 2.3 & 3 & 2.6 & 15 & 2.3 \\
\hline
\end{tabular}

Source(s): Author's Computation.

In consonance with AMJU's mission, the targeting tool employed enhanced the recruitment of the poor into its programmes. From the sampled clients (table 4.8), about 98\% of AMJU clients are considered at least to be average poor. This recruitment criterion is a major variable in using the propensity score matching methods to establish the adequacy of the non-treatment group.

Table 4.9: Primary Business of Clients at Registration

\begin{tabular}{|c|c|c|c|c|c|c|}
\hline \multirow[b]{2}{*}{ Primary Business } & \multicolumn{2}{|c|}{ Treatment Group } & \multicolumn{2}{|c|}{ Non-Treatment Group } & \multicolumn{2}{|c|}{ All Clients } \\
\hline & $\begin{array}{l}\text { No. } \\
523\end{array}$ & $\%$ & $\begin{array}{l}\text { No. } \\
117\end{array}$ & $\%$ & $\begin{array}{l}\text { No. } \\
640\end{array}$ & $\%$ \\
\hline Crop production & 61 & 11.7 & 4 & 3.4 & 65 & 10.2 \\
\hline Animal Production & 8 & 1.5 & 1 & 0.9 & 9 & 1.4 \\
\hline Soap Production & 8 & 1.5 & 2 & 1.7 & 10 & 1.6 \\
\hline Catering Services & 7 & 1.3 & 6 & 5.1 & 13 & 2.0 \\
\hline Restaurant Services & 19 & 3.6 & 8 & 6.8 & 27 & 4.2 \\
\hline Tailoring & 24 & 4.6 & 3 & 2.6 & 27 & 4.2 \\
\hline Hair Dressing & 18 & 3.4 & 8 & 6.8 & 26 & 4.1 \\
\hline Selling "Okika" Cloths & 28 & 5.4 & 3 & 2.6 & 31 & 4.8 \\
\hline Selling New Cloths & 14 & 2.7 & 14 & 12.0 & 28 & 4.4 \\
\hline Selling Agro Crops & 16 & 3.1 & 5 & 4.3 & 21 & 3.3 \\
\hline Shop for Foodstuff & 53 & 10.1 & 21 & 17.9 & 74 & 11.6 \\
\hline Provision/Cosmetic Shop & 68 & 13.0 & 14 & 12.0 & 82 & 12.8 \\
\hline Selling Livestock & 10 & 1.9 & 2 & 1.7 & 12 & 1.9 \\
\hline Kiosk for Foodstuff & 23 & 4.4 & 7 & 6.0 & 30 & 4.7 \\
\hline Kiosk for Provision/Cosmetic & 16 & 3.1 & 5 & 4.3 & 21 & 3.3 \\
\hline Employed worker & 3 & 0.6 & 1 & 0.9 & 4 & 0.6 \\
\hline Labourer & 2 & 0.4 & 1 & 0.9 & 3 & 0.5 \\
\hline Farming & 144 & 27.5 & 12 & 10.3 & 156 & 24.4 \\
\hline Others & 1 & 0.2 & 0 & 0.0 & 1 & 0.2 \\
\hline
\end{tabular}

\section{Source(s): Author's Computation.}

About sixty percent $(60 \%)$ of the sampled clients are high turnover businesses of petty trading (e.g. restaurant/catering services, hair dressing, selling of second-hand and new clothes, shop for foodstuff, 
provision/cosmetic shops/kiosk) which is usually a pre-condition for regular repayment programmes of microfinance. These types of small enterprises are usually supported through micro-loans. Also, the homogeneity in the type of businesses facilitates the group lending methodology. This may appear to present a threat to the livelihood of the group due to correlated business risks. However, there is an inherent opportunity as it helps to lower monitoring costs of group members because of their technical familiarity with other members' business activities (Pagura, 2003).

Table 4.10: Level of Poverty Reduction Among Treatment Group

\begin{tabular}{|l|c|c|}
\hline \multirow{2}{*}{ Poverty Score } & \multicolumn{2}{|c|}{ Treatment group } \\
\cline { 2 - 3 } & No. & $\%$ \\
\hline Reduced by 56 points and above & 523 & 0.8 \\
Reduced by 46-55 points & 4 & 0.4 \\
Reduced by 36-45 points & 2 & 2.5 \\
Reduced by 26-35 points & 13 & 5.0 \\
Reduced by 16-25 points & 26 & 21.6 \\
Reduced by 1-15 points & 113 & 52.8 \\
No change (zero points) & 276 & 12.2 \\
Increased by 1-15 points & 64 & 4.6 \\
Increased by 16-25 points & 24 & 0.2 \\
\hline
\end{tabular}

\section{Source(s): Author's Computation.}

The level of poverty reduction (table 4.10 ) among the treatment group shows that $82.0 \%$ of the clients noticed a reduction in their poverty score as a result of accessing loans from the AMJU programmes. The reduction in poverty level cuts across the eligibility criteria (irregular household income, poor nutritional status, unhealthy condition of dwelling place; etc) for recruitment of clients into AMJU programmes. The revelation enhances the attainment of AMJU's mission of targeting the poor. Nonetheless, $4.8 \%$ claimed that their level of poverty has worsened while about $12.2 \%$ did not notice any change in their poverty status after accessing loan from the programme. A major reasons is that the loan amount is too small to meet their business expansion requirements. It is therefore imperative that producer design should take into consideration the peculiar needs of certain clients instead of providing one-size fit-all products to all clients.

\subsection{Policy Implications of Findings}

The empirical findings of this study have the following policy implications that will help in the implementation of the national microfinance development strategy.

(i) A one-size-fits-all model microfinance delivery mechanism is counter-productive. Instead, MFIs should conduct their operations using a combination of delivery methodology (group or individual) that differentiates among the macroeconomic environment including spatial dispersion of population and other microfinance - driven characteristics (e.g. nature of clients' business and gender concentration).

Policy makers should encourage the conduct of impact evaluation particularly on certain intermediate indicators. Inter-temporal behavioural responses of participants in a programme are relevant to understanding their impacts (see Ravallion \& Chen, 2005).

(iii) A major challenge for policy makers is to design policies that promote microfinance practice. Microfinance policy should take into consideration the congruence between commercial objective and poverty outreach. This will ensure that impact assessment is not relegated to the backstage as a result of too much emphasis on institutional sustainability. Also, it is imperative to get this policy presumptuously right from the outset through consultations with all relevant stakeholders in the microfinance industry and pilot testing.

\subsection{Summary of Findings, Conclusion and Recommendation \\ 5.1 Summary of Findings}

The main objective of this study is to determine how effective microfinance policies are in the Nigerian context in reducing poverty of target clients. The Nearest Neighbour, Radius and Kernel Matching Techniques based on propensity scores were used to analyse the effect of client registration in AMJU programmes. The following are summary of findings.

(i) As demonstrated by the increase in the exit rate, AMJU may consider innovations in delivery mechanism particularly the area of evolving individual lending for those clients that have attained some level of stability and relative independence in their businesses.

(ii) Also, AMJU needs to review loan sizes since many members expressed dissatisfaction with small loan size. Failure to increase loan size may force some active members to drop out from the 
programme. It is important to keep in mind that for any financial service to have a lasting impact on poverty reduction, it should be delivered in flexible way and innovative to adapt to the needs of its clients. This product will enhance high repayment rate, engender business continuity and customer loyalty.

In all, there were indicators that clients who have accessed loans (treatment group) are somewhat better off than those that are yet to benefit. The study has also helped to clarify the misconception that propensity score matching (PSM) needed to be modified in the presence of choice-based sampling, over - or under-sampling of treatment group as in Heckman, Ichimura, Smith and Todd (1998) and Heckman, Ichimura and Todd (1997).

\subsection{Conclusion and Recommendations}

One of the areas of interest to these stakeholders is the determination of impact of microfinance. In other words, impact assessment of microfinance intervention became a major issue in the development paradigm. In recent years, researches on impact evaluation produced mixed results due to environmental peculiarities, evaluation method applied by the researchers and operational methodologies by the various microfinance institutions.

Nonetheless, despite the conflicting findings, attempts are still being made to ascertain the efficacy of microfinance in delivering the desired promise of poverty reduction. Unfortunately, most of the previous impact assessment focused on Latin America and Asia with little attention to Africa especially Nigeria. Therefore, this study is part of the ongoing efforts in the application of the growing field of microeconometrics in impact evaluation programmes. The study used a successful microfinance institutions, AMJU as a study sample.

The findings in the study reveal that microfinance delivery mechanism such as proper client targeting, appropriate product design, flexible regulatory stance is central to operational methodology. In particular, the study confirmed the assertion that repeat loan is an important feature of microfinance in achieving its poverty reduction objectives.

The following recommendations were made at the end of our study and includes;

i. Delivery methodology for microfinance should be tailored after their individual operational strategy and client target.

ii. Feedback mechanism should be built into product delivery to enable impact evaluation of target participants' responses.

iii. Microfinance policies should take cognizance of commercial objective and poverty outreach.

\section{References}

Abadie, A., \& Imbens, G. (2006). "Large sample properties matching estimators for average treatment effects". Econometrica, 74(1), 235-267.

Adams, D.W., Graham, D.H., \& Von Pischke, J.D. (1984). Undermining rural development with cheap credit. Boulder: Westview Press.

Amin, S., Rai, A.S., \& Ropa, G. (2003). "Does microcredit reach the poor and vulnerable? Evidence from Northern Bangladesh". Journal of Development Economics, 70, 59-82.

Angrist, J.D. (2004). "Treatment effects heterogeneity in theory and practice". The Economic Journal, 114, C52, C83.

Angrist, J.D., Imbens, G.W., \& Rubin, D.B. (1996). "Identification and causal effects using instrumental variables". Journal of the American Statistical Association, 90, 431-442.

Angrist, J., Graddy, K., \& Imbens, G. (2000). "The interpretation of instrumental variables estimators in simultaneous equations models with an application to the demand for fish". Review of Economics Studies, 67, 499-527.

Anyanwu, C.M. (2004). "Microfinance institutions in Nigeria: policy practice and potentials". Paper presented at the G-24 Workshops on constraints to growth in Sub-Sahara Africa Pretoria, South-Africa November 29-30.

Armendariz de Aghion, B., \& Morduch, J. (2005). The economics of microfinance. London: The MIT Press Cambridge.

Aryeetey, E. (1994). "Financial integration and development in Sub-Saharan Africa: A studyt of informal finance in Ghana". Working Paper No. 78, Overseas development institute, London.

Aryeetey, E. (1995). "Filling the niche: informal finance in Africa". Nairobi: East Africa Educational Publishers.

Aryeetey, E. (2004). "Mobilisation of private savings for financing prop-poor growth: a seminar paper on financing pro-poor growth in Africa”. AERC Senior Policy Seminar VI< Kampala, Uganda, March 2-4.

Aryeetey, E., \& Hyuha, M. (1991). "The informal financial sector and markets in Africa: an empirical study". In Economic Reform in Sub-Saharan Africa. Edited by A. Chhibber and S.Fishcher. the world bank, Washington DC: $125-136$.

Aryeetey, E., \& Udry, C. (1997). "The characteristics of informal financial markets in sub-Saharan Africa”. Paper presented to the plenary session of the research workshop of the African economic research consortium. 
African Economic Research Consortium, Nairobi, Kenya.

Aryeetey, E., Hettige, H., Nissanke, M., \& Steel, W. (1997a). "Financial market fragmentation and reforms in Ghana, Malawi, Nigeria and Tanzania". The World Bank Economic Review, 11(2), 195-219.

Aryeetey, E., Senbet, L., \& udry, C. (1997b). "Financial liberalisation and financial markets in Sub-Saharan Africa: a synthesis". Journal of African Economics, 1 (Supplement), 1-28.

Baker, J.L. (1999). "Evaluating the poverty impact of projects. A handbook for practitioners". LCSPR/PRMPO, The World Bank.

Barr, M.S. (2004). "Microfinance and financial development". Michigan Journal of International Law, 26, 271296.

Beck, T., Demirguc-Kunt, A., \& Levine, R. (2000). "A new database on the structure and development of the financial sector". World Bank Economic Review, 14(3), 597-605.

Becker, S.O., \& Ichino, A. (2002). "Estimation of average treatment effects based on propensity score". Stata Journal, 2(4), 358-377.

Besley, T. (1994). "How do market failures justify interventions in rural credit markets?" The World Bank Research Observer, 9(1), 27-47.

Besley, T., \& Coate, S. (1995). "Group lending, repayment incentives and social collateral". Journal of Development Economics, 46, 1-18.

Blomquist, J. (2003). "Impact evaluation of social programmes: a policy perspective". Social Protection Human Development Network.

Brau, J.C., \& Woller, G.M. (2004). "Microfinance: a comprehensive review of t4he existing literature". Journal of Entrepreneurial Finance and Business Ventures, 9(1), 1-26.

Caliendo, M., \& Kopeing, S. (2005). "Some practical guidance for the implementation of propensity score matching”. IZA Discussion Paper No. 1588.

Cameron, A.C., \& Trivedi, P.K. (2005). Microeconometrics: methods and application. Cambridge: Cambridge University Press.

Cameron, R., Crips, O., Patrick, H.T., \& Tilly, R. (1967). Banking in the early stages of industrialization. London: Oxford University Press.

Central of Bank of Nigeria (2005). The Nigerian national microfinance policy.

Chase, R. (2002). "Supporting communists in transition: the impact of the Armenian social investment fund". World Bank Economic Review, 16(2), 219-240.

Christen, R.P., Rhyne, E., Vogel, R., \& McKean, C. (1995). "Maximising the outreach of microenterprise finance: an analysis of successful microfinance programmes". USAID Programme and operations assessment report No. 10. Washington D.C. US. Agency for International Development.

Christen, R.P. (2001). "Commercialization and mission drift: the transformation of microfinance in Latin America”. CGAP Occasional Paper No.5 Washington, D.C.

Emran, M.S., Morshed, A.K.M., \& Stiglitz, J.E. (2006). "Microfinance and missing markets". Draft article, march 2006, 1-31.

Essama-Nssah, B. (2006). "Propensity score matching and policy impact analysis". Poverty reduction group, World Bank, Washington, D.C., May.

Faridi, R. (2004). "Essays on microedit programmes and evaluation of women's success". A Ph.D Thesis submitted to faculty of the Virginia Polytechnic Institute and State University.

Frolich, M. (2004). "Finite sample properties of propensity-score matching and weighting estimators". The Review of Economics and Statistics, 86, 77-90.

Frolich, M. (2005). Advanced microeconometrics, AERC-CPP JFE, October 2005.

Frolich, M. (2006). "Propensity score matching without conditional independence assumptions - with an application to the gender wage gap in the UK". University of St. Gallen.

Galasso, E., \& Ravallion, M. (2004). "Social protection in a crisis: Argentina's Plan Jefas Y Jefas". World Bank Economic Review, 18(3), 367-399.

George, S. (1990. A fate worse than debt. London: Penguin

Haln, J. (1998). "On the role of the propensity score in efficient semiparametric estimation of average treatment effects". Econometrica, 66(2), 315-331.

Heckman, J. (1992). "Randomisation and social programme evaluations". In evaluating welfare and training programmes", ed Manski, C.E. and I. Garfinkel. Cambridge: Harvard University Press, 201-230.

Heckman, J. (1997). "Instrumental variables: a study of implicit behavioural assumptions used in making programme evaluations". Journal of Human Resources, 32(3), 441-462.

Heckman, J., Ichimura, H., \& Todd, P. (1977). "Matching as an econometric evaluation estimator: evidence from evaluating a job training programme". Review of Economic Studies, 64(4), 605-654.

Heckman, J., Ichimura, H., Smith, J., \& Todd, P. (1978). "Characterising selection bias using experimental data”. Econometrica, 66(5), 1017-1098. 
Heckman, J., \& Hotz, J. (1989). "Choosing among alternative non-experimental methods for estimating the impact of social programmes: the case of manpower training". JASA, 84(19989), 862-868.

Heckman, J., LaLonde, R., \& Smith, J. (1999). "The economics and econometrics of active labour market programmes". In handbook of labour economics Vol III. Ed by Ashenfelter and Card, D., 1865-2097. Elsevier, Amsterdam.

Hirano, K., Imbens, G., \& Ridder, G. (2003). "Efficient estimation of average treatment effects using the estimated propensity score". Economeltrica, 71, 1161-1189.

Hulme, D. (1997). "Impact assessment methodologies for microfinance: a review - assessing the impact of microenterprise services". Washington, D.C: Management Systems International.

Hulme, D., Mosely, P. (1996). Financing against poverty. London: Routledge.

Imbens, G. (2000). "The role of the propensity score in estimating dose-response functions". Biometrika, 87(3), 706-710.

Iyoha, M.A. (1998). "Rekindling investment for economics development in Nigeria: the macroeconomics issues". In Aibgokhan, B.E. (Ed.) Rekindling investment for economics development in Nigeria. Selected papers for the 1998 Annual Conference of the Nigeria Economics Society. Ibadan: NES.

Johnson, S. (2005). "Rural financial markets". In Green, C.J., Kirkpatrick, C.H. and Murinde, V. (eds). Finance and development: surveys of theory, evidence and policy. Edward Elgar, 315-355.

Johnson, S. \& Rogaly, B. (1997). Microfinance and poverty reduction. UK and Ireland: Oxfam.

Kabeer, N. (2003). "Safety nets and opportunity ladders: addressing vulnerability and enhancing productivity in South Asia", in Sarah Cook, Naila Kabeer and Gary Suwannarat (eds.) social protection in Asia. the ford foundation, Published by Har-Arnand Publications Pvt Ltd.

Kabeer, N. (2005). "Is microfinance a magic bullet for women's empowerment? Analysis of findings from South Asia". Economic and Political Weekly, 4709-4718.

Kaboski, J., \& Townsend, R. (2005). "Politics and impact: an analysis of village-level microfinance institutions". Journal of European Economic Association, 3(1).

Kalpana, K. (2004). "The shifting trajectories in microfinance discourse - is it an anti-poverty Waepon"?

Karlan, D.S. (2001). "Microfinance impact assessments: the perils of using new members as a control group". Journal of Microfinance, 3: 75-85.

Karlan, D.S., \& Goldberg, M. (2006). "The impact of microfinance: a review of methodological issues".

Laechner, M. (2001). "Identification and estimation of casual effects of multiple treatments under the conditional independence assumption". In Econometric evaluation of labour market policies, ed. By M. Lechner, and F. Pfeiffer, 1-18, Physica-Verlag, Heidelberg.

Manski, C.F. (1990). "Nonparametric bounds on treatment effects". America Economic Review Papers and Proceedings, 80, 319-542.

Mansk, C.F. (1996). "Learning about treatment effects from experiments with random assignment of treatments". Journal of Human Resources, 31, 709-733.

Mishra, P. (1994). "Crop insurance and crop credit: impact of comprehensive crop insurance scheme on cooperative credit in Gujarat". Journal of International Development, 6, 529-568.

Misra, A. (2006). "Microfinance in India and millennium development goals: maximizing impact on poverty". Discussion Paper for Workshop on World Bank, Singapore, September, 2006.

Montgomery, R. et al (1996). "Disciplining or protecting the poor? Avoiding the social costs of peer pressure in micro-credit schemes". Journal of International Development, 8, 289-305.

Montgomery, H., \& Weiss, J. (2005). "Great expectations: microfinance and poverty reduction in Asia and Latin America”. ADB Institute Research Paper Series No. 63.

Morduch, J. (1998). "Does microfinance really help the poor?" News evidence from flagship programmes in Bangladesh". Unpublished manuscript. Cambridge: Department of Economics and HIID, Harvard University.

Morduch, J. (1999). "The microfinance promise”. The Journal of Economic Literature, 37(4), 1569-1614.

Morduch, J. (2000). "The microfinance schism". World Development, 28, 617-629.

Morduch, J. (2003). "Can the poor pay more? Microfinance and returns to capital in Indonesia". Mimeo.

Morduch, J., \& Haley, B. (2002). “Analysis of microfinance on poverty reduction. NYU Wagner Working Paper Series, June, No. 1014.

Mosley, P., \& Hulme, D. (1998). "Microenterprise finance: is there a conflict between growth and poverty alleviation?" World Development, 26, 783-790.

Mutua, K., Nataradol, P., Otero, M., \& Chun, B. (1996). “The view from the field: perspectives from managers of microfinance institutions". Journal of International Development, 8, 179-193.

Nair, Tara, S. (2001). "Institutionalizing microfinance in India". Economic and Political Weekly, XXXVI(4) (January).

National Bureau of Statistics (2005). Results of the poverty profile survey in Nigeria.

Nissanke, M. (1991). "Mobilising domestic resources for African development and diversification: structural 
impediments to financial int4ermediatioin”. In economic reform in Sub-Saharan Africa, ed. Chhibber, A. and Fischer, S., The world bank. Washington, D.C. 137-147.

Obadan, M.I. (1997). "The free enterprise system and the development of African economics". Nigerian Economics and Financial Review, 2.

Obadan, M.I. (2003). National development planning and budgeting in Nigeria: some pertinent issues. Lagos: Broadway Press Limited.

Ogiogio, G. (2006). "Impact measurement of capacity building intervention". ACBF Occasional Paper.

Okojie, C.E.E. (2002). "Development planning in Nigeria since independence". In Iyoha, M.A. and Itsede, C.O., eds, Nigerian economy: structure, growth and development, Benin City: Mindex Publishing.

Okojie, C.E.E., Anyanwu, J.C., Ogwumike, F.O., \& Alayande, B.A. (2000). "Poverty in Nigeria: An analysis of gender issues. Access to social services and the labour market". A Research Report submitted to the African Economic Research Consortium, Nairobi, Kenya.

Osthoft, J. (2005). "Is microfinance an effective development tool in the content of poverty alleviation? Evaluating the case of rural China". MA project (International Economic Management), university of Birmingham.

Otero, M. (1989). "A handful of rice" savings of mobilization by micro-enterprise programmes and perspectives for their future". Accion International Monograph Series No. 3 Washington, D.C.

Otero, M. (1994). "The evolution of non-governmental organisations towards financial intermediation". In the new world of microenterprise finance: building healthy institutions for the poor. Ed. Otero, M. and E. Rhyne, West Har4tford, C.T.: Kumarlin Press, 105-116.

Otero, M. (1999). "Bringing development back into microfinance". Paper delivered at conference on new development finance, Goethe University, Frankfurt, September.

Oyejide, T.A. (1993). "Financial liberalization under structural adjustment and its implications for financing smallscale and microenterprises in Nigeria". In A.H.J. Helmising and T. Kolstee (1993). Small enterprises and changing policies. London: IT Publications.

Pagura, M.E. (2003). "Examining client exit microfinance: theoretical and empirical perspectives". Ph.D. Dissertation, Graduate school, The Ohio State University.

Ravallion, M. (2005). "Evaluating anti-poverty programme”. Handbook of development economics, 4.

Rosenbaum, P., \& Rubin, D. (1983). "The central role of the propensity score in observation studies for causal effects". Biometrika, 70, 41-55.

Rosenbaum, P., \& Rubin, D. (1985). "Constructing a control group using multivariate matched sampling methods that incorporate the propensity score". The American Statistician, 39(1), 33-38.

Rubin, D.B. (1974). "Estimating causal effects of treatments in randomized and non-randomised studies". Journal of Educational Psychology, 66, 688-701.

Smith, S. (2002). "Village banking and material and child health: evidence from Ecuador and Honduras". World Development, 30(4), 707-723.

Soyibo, A. (1996). Financial linkage and development in Sub-Saharan Africa: a study of informal finance in Nigeria". Working Paper 90, Overseas Development Institute, London.

Soyibo, A. (2004). "Financial sector reforms policies, growth and poverty reduction in Africa: a seminar paper on financing pro-poor growth in Africa”. AERC senior policy seminar VI, Kampala,, Uganda, March 2-4.

Udry, C. (1993). "Credit markets in northern Nigeria: credit as insurance in rural economy". The World Bank Economics Review, 4(3), 251-269.

UNCDF (2003). "Nigeria companion report". UNCDF Microfinance Programme Assessment.

Van Tassel, E. (1999). "Group lending under asymmetric information”. Journal of Development Economics. 60, 229-248.

Van Tassel, E. (2003). "Household bargaining and microfinance". Seminar Paper, Department of Economics, Florida Atlantic University

Wai, U.T. (1992). "What have we learned about informal finance". In three decades in informal finance in lowincome countries, eds, Adams, D.W. and Fitchett, D.A., 337-348.

Weiner, M. (1995). "Group credit: a means to improve information transfer and loan repayment performance". Journal of Development Studies, 32, 263-281.

Wooldridge, J.M. (2002). Econometric analysis of cross section and panel data. London: The MIT Press Ambridge, Massachusetts.

World Bank (2000). "Assessing the relative poverty levels of MFI clients". Washington: World Bank.

World Bank. (2001). World development report 2000/01: attacking poverty. Washington: World Bank.

World Bank (2002). "Monitoring and evaluation: some tools, methods and approaches". Operations Evaluation Department, World Bank, Washington D.C.

Wydick, W.B. (1999). "The effect of microenterprise lending on child schooling in Guatemala". Economic Development and Cultural Change, 47u, 853-869.

Zeller, M., \& Meyer, R.L. (2002). "The triangle of microfinance: financial sustainability outreach and impact". 
John Hopkins for the International Food Policy Research Institute, Baltimore.

Zhao, Z. (2003). "Data issues of using matching methods to estimate treatment effects: an illustration with NSW Data Set". China centre for Economic Research, Perking University.

Zhao, Z. (2004). "Using matching to estimate treatment effects: data requirements, matching metrics, and Monte

Carlo evidence". The Review of Economic and Statistics, 86(1), 91-107.

APPENDIX

SUSTAINABILITY AND SUCCESS INDICATORS OF AMJU

\begin{tabular}{|c|c|c|c|c|c|}
\hline $\begin{array}{l}\text { Performance } \\
\text { indicator }\end{array}$ & 2013 & 2014 & 2015 & 2016 & 2017 \\
\hline \multicolumn{6}{|l|}{ Outreach-Breadth } \\
\hline No. of Branches & 3 & 5 & 9 & 9 & 13 \\
\hline No. of Clients & 17,578 & 21,766 & 24,563 & 32,938 & 48,735 \\
\hline No. of new clients & 5,744 & 11,019 & 14,782 & 22,208 & 31,167 \\
\hline No. of Women & 16,699 & 20,678 & 24,072 & 32,279 & 46,298 \\
\hline $\begin{array}{l}\text { No. of active } \\
\text { borrowers }\end{array}$ & 13,859 & 18,740 & 23,136 & 29,812 & 43,699 \\
\hline $\begin{array}{l}\text { Total loans } \\
\text { disbursed }(\#)\end{array}$ & $86,584,195.00$ & $194,476,200.00$ & $361,190,050.00$ & $620,517,150.00$ & $1,005,827,500.00$ \\
\hline \multicolumn{6}{|l|}{ Outreach-Depth } \\
\hline $\begin{array}{l}\text { Average loan } \\
\text { (total loan/No. of } \\
\text { active } \\
\text { borrowers( }(\mathbb{N})\end{array}$ & 6,248 & 10,378 & 15,612 & 20,814 & 23,017 \\
\hline $\begin{array}{l}\text { Clients drop-out } \\
\text { rate }\end{array}$ & $8.57 \%$ & $14.18 \%$ & $21.00 \%$ & $22.21 \%$ & $31.17 \%$ \\
\hline \multicolumn{6}{|l|}{ Screening } \\
\hline $\begin{array}{l}\text { Cost of loan } \\
\text { administration } \\
\text { (N) }\end{array}$ & $\mathrm{n} / \mathrm{a}$ & $45,629,299.00$ & $779,888,073.00$ & $111,071,728.00$ & $149,029,707.00$ \\
\hline \multicolumn{6}{|l|}{ Enforcement/Risk } \\
\hline $\begin{array}{l}\text { Outstanding } \\
\text { balance of loans } \\
\text { exceeding } 90 \text { days } \\
\text { (A) }\end{array}$ & $11,298,423.00$ & $11,073,419.00$ & $14,424,323.00$ & $2,641,531.00$ & $4,713,112.00$ \\
\hline $\begin{array}{l}\text { Outstanding } \\
\text { balance/total loan }\end{array}$ & 0.1305 & 0.0569 & 0.0399 & 0.0043 & 0.0047 \\
\hline Total bad debt ( $\mathbb{\#}$ & $\mathrm{n} / \mathrm{a}$ & $5,666,794.00$ & $725,551.00$ & ---- & $5,927.00$ \\
\hline PAR 30 days & & & & & \\
\hline $\begin{array}{l}\text { No. of credit } \\
\text { officers }\end{array}$ & 54 & 69 & 90 & 114 & 149 \\
\hline \multicolumn{6}{|c|}{$\begin{array}{l}\text { Institutional performance } \\
\text { (staff productivity) }\end{array}$} \\
\hline $\begin{array}{l}\text { Total clients/loan } \\
\text { officer }\end{array}$ & 326 & 315 & 273 & 289 & 327 \\
\hline $\begin{array}{l}\text { Total cost of loan } \\
\text { admin/loan } \\
\text { officer }\end{array}$ & $\mathrm{n} / \mathrm{a}$ & 661,294 & $8,665,423$ & 974,313 & $1,000,199$ \\
\hline No. of staff & 28 & 35 & 43 & 56 & 63 \\
\hline Staff turnover rate & 5.36 & 5.59 & 14.74 & 8.78 & 6.78 \\
\hline $\begin{array}{l}\text { Total income } \\
\text { from loans }(\#)\end{array}$ & $11,628,355.00$ & $288,249,232.00$ & $53,631,198.00$ & $104,131,897.00$ & $157,406,505.00$ \\
\hline $\begin{array}{l}\text { Total income } \\
\text { from donors }(\mathbb{N})\end{array}$ & $10,229,070.00$ & $14,552,119.00$ & $748,200.00$ & --- & $60,973,392.00$ \\
\hline $\begin{array}{l}\text { No. of credit } \\
\text { officers }\end{array}$ & 54 & 69 & 90 & 114 & 149 \\
\hline
\end{tabular}




\begin{tabular}{|c|c|c|c|c|c|}
\hline $\begin{array}{l}\text { Performance } \\
\text { indicator }\end{array}$ & 2013 & 2014 & 2015 & 2016 & 2017 \\
\hline $\begin{array}{ll}\text { No. } & \text { of } \\
\text { groups/unions }\end{array}$ & 547 & 585 & 1400 & 1885 & 2546 \\
\hline No. of fraud cases & & & 4 & 5 & 3 \\
\hline $\begin{array}{l}\text { Total value of } \\
\text { fraud ( })\end{array}$ & & & $253,010.00$ & $203,720.00$ & $192,290.00$ \\
\hline $\begin{array}{l}\text { Number of } \\
\text { union/loan officer }\end{array}$ & 10 & 8 & 16 & 17 & 17 \\
\hline \multicolumn{6}{|l|}{$\begin{array}{l}\text { Administrative } \\
\text { Efficiency }\end{array}$} \\
\hline $\begin{array}{l}\text { Admin Exp/Total } \\
\text { loan }\end{array}$ & & - & - & - & - \\
\hline 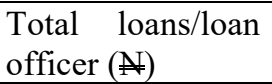 & $1,603,411.02$ & $2,818,495.65$ & $4,013,222.78$ & $5,443,132.89$ & $6,750,520.13$ \\
\hline \multicolumn{6}{|l|}{ Interest Charge } \\
\hline $\begin{array}{l}\text { Interest rate of } \\
\text { loans }\end{array}$ & $36 \%$ & $36 \%$ & $36 \%$ & $36 \%$ & $36 \%$ \\
\hline T-bill rate & $0 \%$ & $0 \%$ & $0 \%$ & $0 \%$ & $0 \%$ \\
\hline Interest premium & $36 \%$ & $36 \%$ & $36 \%$ & $36 \%$ & $36 \%$ \\
\hline
\end{tabular}

Source: AMJU Admin Records at Head Office. 